M yroslava Polutrenko ${ }^{1}$ and Andriy Pilyashenko- N ovokhatnyi ${ }^{2}$

\title{
EFFECT OF NITROGEN ATED CORROSION INHIBITORS ON THE GROWTH AND FERMENT ACTIVITY OF SULFUR CYCLE BACTERIA
}

\author{
1 Ivano-Frankivsk National Technical University of Oil and Gas (IFNTUOG), \\ 15, Karpatska str., 76019 Ivano-Frankivsk, Ukraine; no@ nung.edu \\ 2 Open International University of Human Development "Ukraine", \\ 23, Lvivska str., Kyiv, Ukraine; apilya@online.ua
}

Received: December 06, 2012 / Revised: J anuary 31, 2013 / Accepted: M ay 28, 2013

(C) Polutrenko M., Pilyashenko-Novokhatnyi A., 2013

\begin{abstract}
The effect of industrially manufactured corrosion inhibitors ("G", "K", "L", "M", and "N" inhibitors) on the biological activity of thione (TB) and sulfate reducing (SRB) bacteria and corrosive microbial associations has been studied. SRB sensitivity to all the studied inhibitors has been established. The dynamics of hydrogenase reaction blocking under the action of the studied inhibitors as well as inhibition constants have been determined. Nitrogenated corrosion inhibitors are recommended to be used for protecting the subterranean metal structures from microbial corrosion.
\end{abstract}

Keywords: inhibitor, ferment activity, bacteria, dynamics.

\section{Introduction}

In the operation of the main gas and oil pipelines soil bacteria of sulfur cycle concentrated around the subterranean structure are capable of substantially lessening the antirust efficiency of cathode protection [1$3]$. Such an effect is the consequence of a high activity of bacterial redox ferments. In practice, according to the normative documents [2] the minimum protective potential amounts to $-0.85 \mathrm{~V}$ at $\mathrm{Cu} / \mathrm{CuSO}_{4}$ electrode. This value is based on theoretical calculations of electromotive force (EMF) of iron oxidation reaction with oxygen in the neutral environment at the presence of water. Under real conditions of subterranean structures operation in the presence of sulfate reducing bacteria the above value of the protective potential appears to be ineffective. In case of soil corrosion as a result of sulfate reducing bacteria activity iron oxidation occurs without the atmospheric oxygen participation according to the classical cathode depolarization formula:
$4 \mathrm{Fe}^{0} \rightarrow 4 \mathrm{Fe}^{2+}+8 \mathrm{e}$ (on the metal anodic areas)

$8 \mathrm{H}^{+}+8 \mathrm{e}->8 \mathrm{H}$ (on the metal cathodic areas)

$\mathrm{SO}_{4}{ }^{2-}+8 \mathrm{H}->\mathrm{S}^{2-}+4 \mathrm{H}_{2} \mathrm{O}$ (SRB cathodic depolarization)

The total electromotive force of cathode depolarization reaction amounts to $0.60 \mathrm{~V}$. Thus, in case of sulfate reducing the recommended cathode protection potential exceeds the total EMF by $0.24 \mathrm{~V}$, which promotes the increase in SRB corrosive activity in modeling studies and under the field conditions. The necessity of using the additional protective anticorrosive means, namely corrosion inhibitors, is becoming evident. Both at the present time and in the nearest future among the various methods used for protection of the subterranean metal structures from corrosion the leading place is and will be held by inhibitory protection as it does not require substantial capital investment.

The principal advantages of inhibitory protection are its plainness, economic efficiency and the possibility of replacing the existing inhibitor for a more efficient one without breaking the technological chart of the process.

Despite the existing wide range of corrosion inhibitors and bactericides the search for new and more efficient substances, which are capable of acting both as universal inhibitors and bactericides capable of slowing down and even suppressing the bio corrosion processes altogether, is constantly going on. The prerequisite for such inhibitors will be the capability of revealing the bactericidal action and blocking the ferment action of bacteria by the mechanism of the non-competitive inhibition dynamics [4]. The most effective steel corrosion inhibitors are salts and amine, diamine, 
imidazoline derivatives and quaternary ammonium salts [5-7]. The main advantage of organic biocides over the inorganic ones is their high efficiency of action (90$94 \%$ ) with the minimum concentration and stability of biological activity, which is probably connected with their cationic structure. They belong to the IV danger category and can be successfully used under the conditions of anaerobic corrosion due to sulfate reducing bacteria without damaging the environment (2).

On the other hand, nature protection legislation requirements in the recent years have become more severe as to the application of xenobiotic substances in open systems. The application of a number of traditional biocides has been forbidden. The main criterion which determines the possibility of use of the biocidescorrosion inhibitors in the operational practice is low level of ecological toxicity. These must be the substances with low sensitivity to the influence of the changes in the environment which are incapable of forming toxic decomposition products in the course of destruction, i.e. bio-resistant ones.

Summing up the above mentioned two basic requirements to the microbial corrosion inhibitors which are introduced into industrial application can be formulated: biocide characteristics and bio-resistivity. The first of the above requirements has been generally recognized and the study of the inhibitory action of corrosion is being conducted widely. The study of corrosion inhibitors bio-resistivity in terms of the effect of sulfur cycle bacteria on them has been carried out by the authors for the first time.
As the microorganisms responsible for biocorrosion quickly adapt to the existing biocides, which requires the increase of the biocide concentration and therefore increases ecological load on the environment, the selection of the biocides which are active to the associates of the dangerous corrosive microorganisms with minimum concentration of their action remains a topical problem.

The purpose of this paper was the study of the effect of five industrially manufactured inhibitors (" $G$ ", "K", "L", "M", and "N") with the view of determining the biological activity of thione (Thiobacillus thioparus stain 61), sulfate reducing (Desulfovibrio desulfuricans stain 10) bacteria which are kept in the collection of microorganisms of D. Zabolotnyi Institute of Microbiology and Virology, and active corrosive microbial association.

\section{Experimental}

Experimental study of the effect of nitrogenated corrosion inhibitors on the growth and ferment activity of bacteria of sulfur cycle was carried out in accordance with the techniques [7-9, 13]. Sulfate-reducing bacteria cultures were being grown in Postgate B liquid medium during 14 days and nights. Acidophobic thione bacteria were being grown in the thermostat at $301 \mathrm{~K}$ during 7 days and nights in Beyerink nutrient medium [8].

The inhibitors studied belong to the quaternary nitrogenated compounds (Table 1).

Table 1

Used corrosion inhibitors

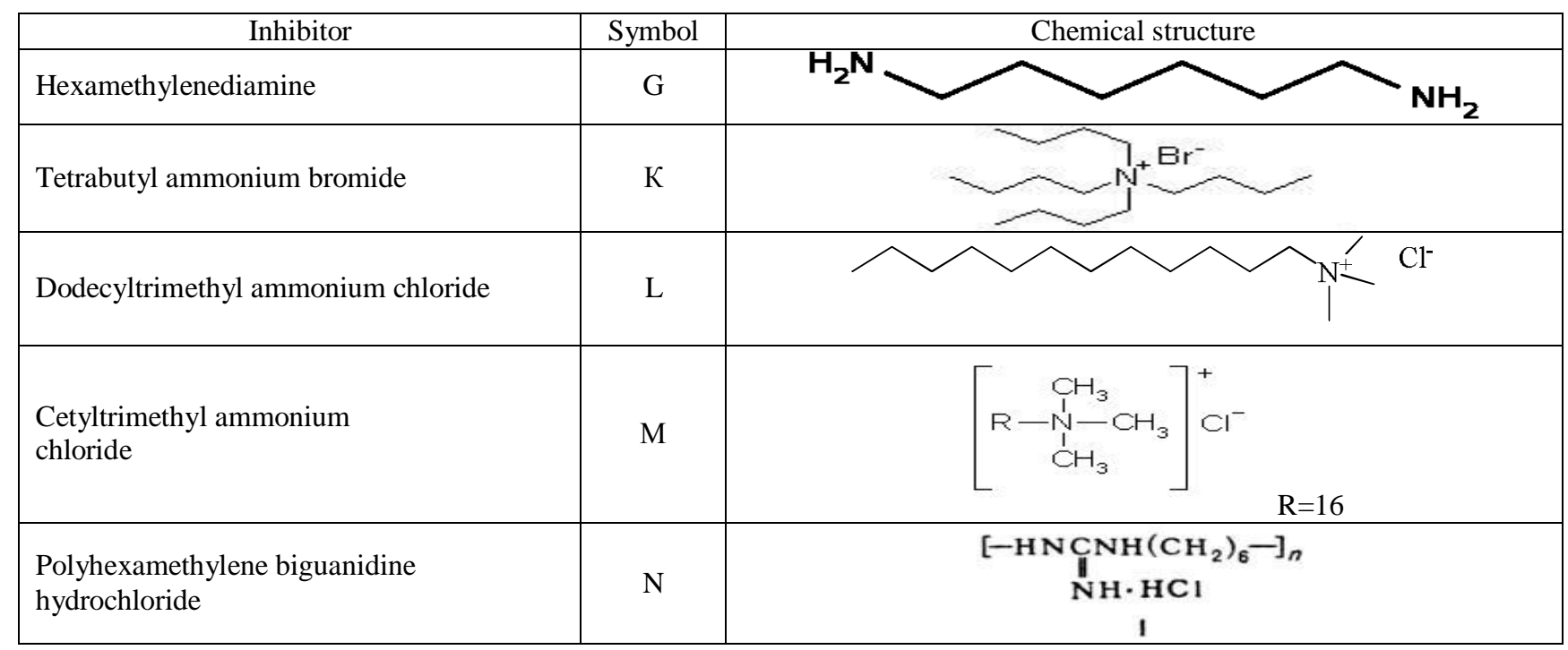




\section{Results and Discussion}

The results of the research show that among the quaternary nitrogenated compounds the leader in terms of the effect on the acidophobic thione bacteria Thiobacillus thioparus stain 61 appeared "N" inhibitor which suppressed their growth by more than $90 \%$.

Close to it in terms of the efficiency of the action appeared the "G" and " $\mathrm{K}$ " inhibitors, which almost by $80 \%$ suppressed the growth rate of the microorganisms studied with the concentration of $0.2 \mathrm{~g} / \mathrm{l}$ (Fig. 1). Less activity was shown by "M" and "L" inhibitors, which with the same concentration blocked the growth rate of thione bacteria by 50 and $60 \%$, respectively.

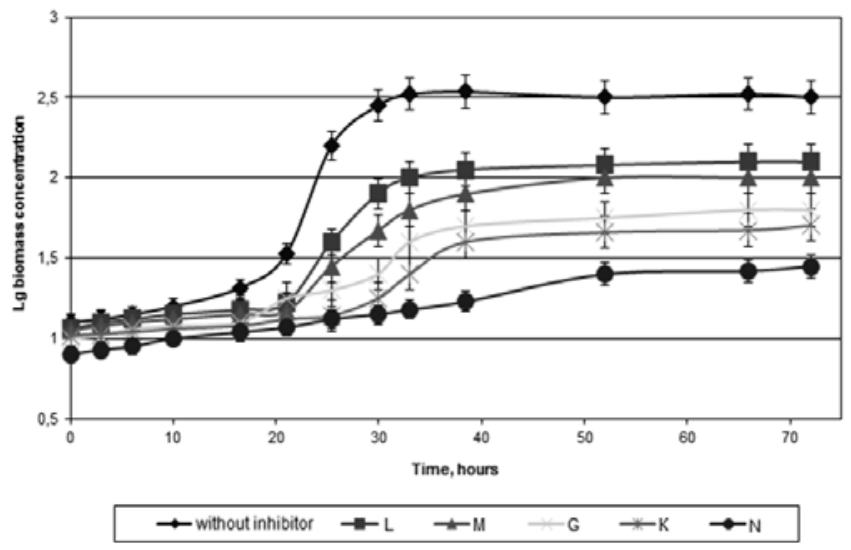

Fig. 1. The effect of quaternary nitrogenous compounds on the growth rate of Thiobacillus thioparus stain 61 (all the inhibitors were taken in the concentration of $0.2 \mathrm{~g} / \mathrm{l}$ )

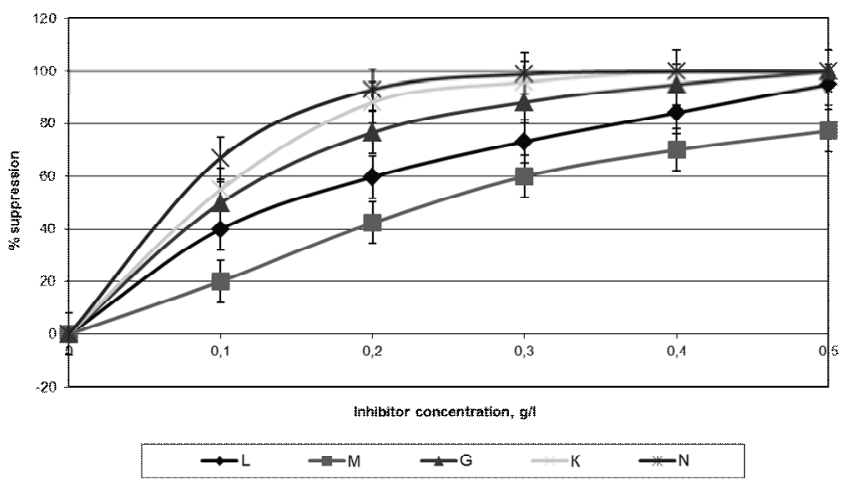

Fig. 2. The effect of quaternary nitrogenated compounds on hydrogenase activity

For sulfate reducing bacteria the basic criterion of their bio-corrosive activity is the activity of hydrogenase ferment. It is with this purpose that the authors have carried out a number of experiments aimed at studying the effect of corrosion inhibitors on the hydrogenase reaction in accordance with the technique [9].
The sensitivity of sulfate reducing bacteria is shown here to all studied inhibitors, what demonstrates the possibility of their application to protect the metals from microbial corrosion of the subterranean metal structures. The leader according to this characteristic among the inhibitors studied is " $N$ " inhibitor as well, which completely blocks the ferment activity of sulfate reducing bacteria with the concentration of $0.3 \mathrm{~g} / \mathrm{l}$ (Fig. 2 ). With growing concentration of inhibitors a complete suppression of the sulfate reducing bacteria growth is observed for " $\mathrm{K}$ " inhibitor with the concentration of $0.4 \mathrm{~g} / \mathrm{l}$; for " $\mathrm{G}$ " inhibitor with with the concentration of $0.5 \mathrm{~g} / \mathrm{l}$; while "L" inhibitor is almost $94 \%$ efficient with the concentration of $0.5 \mathrm{~g} / \mathrm{l}$.

The authors carried out the determination of the dynamics responsible for blocking of growth and ferment activity of the sulfur cycle highly corrosive bacteria [7].

Figs. 3 and 4 show the results of determining the hydrogenase reaction blocking dynamics under the action of the inhibitors studied. One can see that " $G$ " and " $\mathrm{N}$ " inhibitors block the corrosive processes according to the competitive dynamics.

Inhibition dynamics according to the competitive dynamics implies that the inhibitor action can be lessened or completely discarded if its effective concentration decreases, which can be due to excluding of the inhibitor from the reaction medium or additional introduction of the substrate into the reaction medium. Using the graphic method the inhibition constants $\left(K_{i}\right)$ were determined for the given inhibitors, which are $11 \pm 0.5 \mathrm{mg} / \mathrm{l}$ ("G" inhibitor) and $8.8 \pm 0.4 \mathrm{mg} / \mathrm{l}$ ("N" inhibitor).

On the contrary, "K", "L" and "M" inhibitors block the hydrogenase reaction of corrosive SRB according to non-competitive dynamics (Fig. 4).

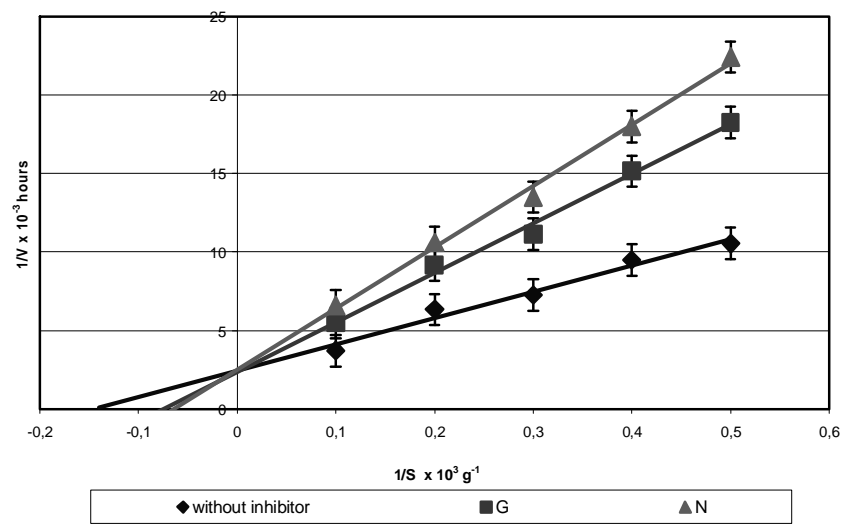

Fig. 3. Competitive inhibition of corrosion processes under the action of Quaternary nitrogenatedcompounds 


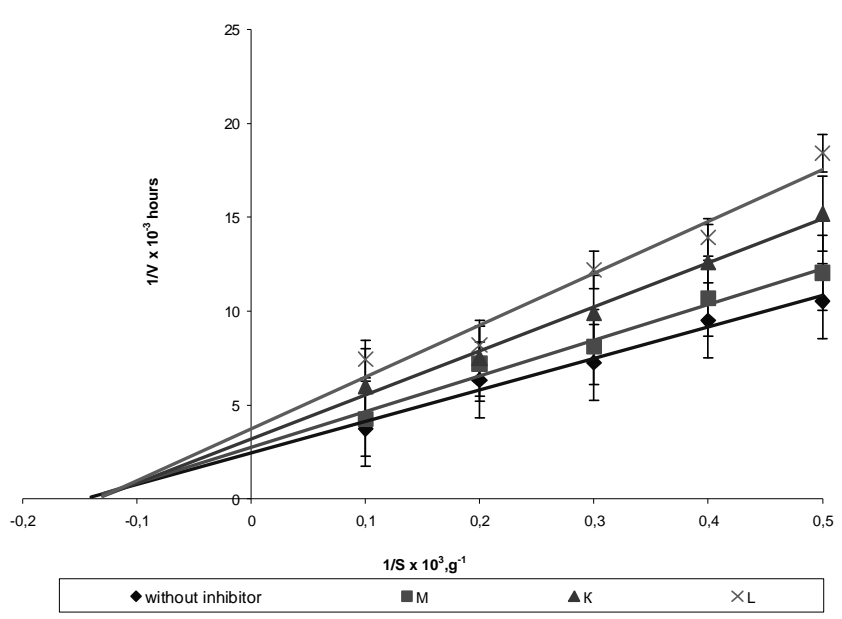

Fig. 4. Non-competitive inhibition of corrosion processes under the action of quaternary nitrogenous compounds

In case of non-competitive inhibition dynamics a non-returning blocking of hydrogenase reaction occurs and the effect caused by the inhibitor action cannot be removed at the expense of increasing substrate concentration in the reaction medium.

For non-competitive " $K$ ", "L", and " $M$ " inhibitors the inhibition constants equal to $9.3 \pm 0.3 \mathrm{mg} / \mathrm{l}$ for " $\mathrm{M}$ " inhibitor, $8.1 \pm 0.3 \mathrm{mg} / \mathrm{l}$ for " $\mathrm{K}$ " inhibitor and $7.2 \pm$ $\pm 0.3 \mathrm{mg} / \mathrm{l}$ for "L" inhibitor.

Close values of inhibition constants have been observed for " $\mathrm{K}$ " inhibitor and "N" inhibitor, however, the latter affects the corrosive processes according to competitive dynamics.

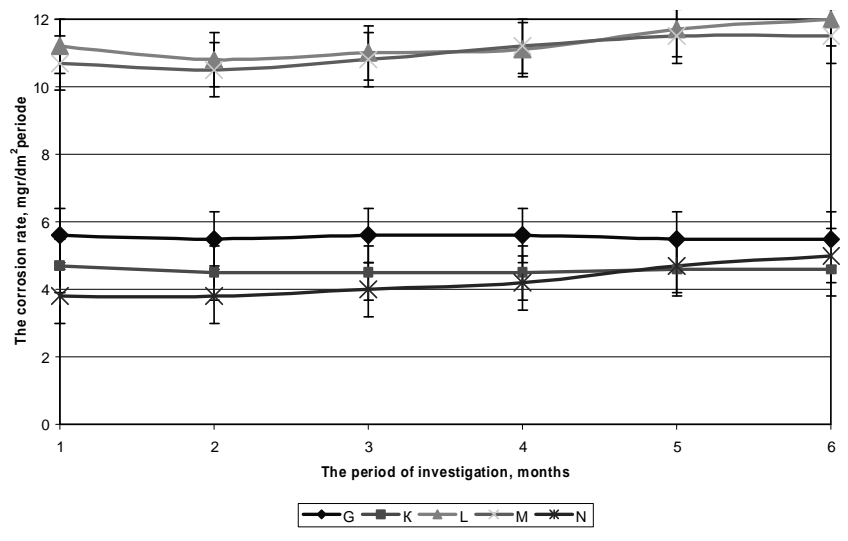

Fig. 5. Effect of inhibitor nature on the corrosion rate of steel specimens

Summing up the above mentioned it can be concluded that in a short-lived laboratory model experiment the best possible biocide properties were displayed by "L" inhibitor. The ultimate evaluation of inhibitor anticorrosion efficiency under the condition of an active development of microorganisms active life will be possible only provided their long-time behavior study, namely, stability to the effect of bacteria - biostability. For this purpose laboratory experiments were made with the view of determining the effect of inhibitors nature on steel $17 \mathrm{G} 1 \mathrm{~S}$ corrosion rate. The exposition period amounted to six months. The corrosion rate of metal specimens which were submerged into the test systems was determined using the gravimetric technique [10].

Fig. 5 shows the results of the research, the analysis of which indicate that in case of " $G$ " and " $K$ " inhibitors the corrosion rate in the test system in fact did not change.

In case of addition of " $\mathrm{M}$ " inhibitor the increase of corrosion rate by $10-15 \%$ was observed by the end of the experiment. For " $\mathrm{N}$ " inhibitor the increase was close to $25 \%$. The observed intensification of corrosion processes under the action of "N" inhibitor can be both due to the increase of SRB bacteria amount and due to the chloride-ions which can be formed in the course of inhibitor degradation.

The laboratory experiments carried out by the authors showed that the inhibitors tested possess bactericide properties and can be used for modeling the innovative inhibiting systems for protecting subterranean metal structures from microbiological corrosion.

Using "G", "L", "M", and "N" inhibitors we obtained the modified bituminous-polymer mastics with better physical and mechanical and hydrophobic properties [11]. Based on the modified mastic with "G" inhibitor the insulated coating has been tested under the field conditions of the Main Gas Pipelines "Prykarpattransgaz". The results of testing of insulated coating applied on the damaged $260 \mathrm{~m}$ long (tested) section of the Rozdilna-Ismail gas pipeline, $820 \mathrm{~mm}$ in diameter on, $55 \mathrm{~km}$ from Berezivka compressor station, showed higher physical and mechanical characteristics of the coating (thickness, shock strength, mastic to metal adhesion, band to mastic adhesion) against the normative indices of the Ukrainian standards [12].

\section{Conclusions}

1. The study on the effect of the nitrogenated corrosion inhibitors on the biological activity of sulfur cycle bacteria was carried out.

2. The sensitivity of sulfate reducing bacteria (SRB) to all the corrosion inhibitors studied was established by the authors.

3. The dynamics of the hydrogenase reaction blocking under the action of the investigated inhibitor was studied and the inhibition constants were determined. 
4. Bio-resistance of nitrogenated corrosion inhibitors to sulfur cycle bacteria effect on them was studied for the first time.

5. It is recommended to use the inhibitors studied for modeling of the innovative inhibiting systems for protection of subterranean metal structures from microbiological corrosion.

\section{References}

[1] Kozlova I., Radchenko O., Stepura L. et al.: Heokhimichna Diyalnist Mikroorganizmiv ta ii Prykladni Aspekty. Naukova dumka, Kyiv 2008.

[2] Andreyuk K., Kozlova I., Koptieva Zh. et al.: Mikrobna Koroziya Pidzemnykh Sporud. Naukova dumka, Kyiv 2005.

[3] Halilton W.: Ann. Rev. Microbio., 1985, 39, 195.

[4] Boichenko S. and Kuchma N.: Visnyk Nats. Avia. Univ., 2004, 4, 161.

[5] Lypovych R., Gonik A., Nizamov K. et al.: Mikrobiologicheskaya Korroziya i Metody yee Predotvrashcheniya. VNIIOENG, Moskwa 1977.

[6] Strizhevsky I.: Podzemnaya Korroziya i Methody Zashchity. Metallurgiya, Moskwa 1986.

[7] Dikson M. and Wuebb E.: Fermenty. Mir, Moskwa 1982.

[8] Romanenko V. and Kuznetsov S.: Ecologiya Microorganizmov Presnykh Vodoemov. Nauka, Leningrad 1974.

[9] Sadkow A., Pilyasheno-Novokhatnyi A., Belova V. et al.: Zh. Prikl. Biokhim. i Microbiol., 1979, 15, 627.
[10] Sukhotin A.: Tekhnika Borby s Korroziey. Khimiya, Leningrad 1980.

[11] Kryzhanivsky E., Fedorovych Y., Polutrenko M. et al.: Rozvidka ta Rozrobka Naft. i Gas. Rodovysh, 2011, 40, 100.

[12] DSTU 3999-2000 Pokryttia Zakhysni Polimerni, Naftobitumni ta Kamianovuhilni. Metody Laboratornykh Vyprobuvan na Biostiykist. Derzhstandart Ukrainy, Kyiv 2001.

[13] Antypchuk A., Pilyashenko-Novokhatnyi A. and Yevdokymenko T.: Praktikum po Microbiologii. Universitet "Ukraina", Kyiv 2011.

\section{ВПЛИВ НІТРОГЕНОВМІСНИХ ІНГІБІТОРІВ КОРОЗIÏ НА РICT TA ФЕРМЕНТНУ АКТИВНІСТЬ БАКТЕРІЙ ЦИКЛУ СІРКИ}

Анотація. Досліджено вплив інгібіторів корозії промислового виробництва (інгібітори: «Г», «K», «Л», «M» $i$ «Н») на біологічну активність тіонових (ТБ), сульфатвідновлювальних (СВБ) бактерій та корозійноактивних мікробних асоиіачій. Встановлено чутливість СВБ до всіх досліджених інгібіторів. Визначено механізм блокування гідрогеназної реакиї під дією досліджуваних інгібіторів, визначено константи інгібування. Нітрогеновмісні інгібітори корозії рекомендовано до використання для захисту від мікробної корозії підземних металевих конструкцій.

Ключові слова: інгібітор, ферментна активність, бактерї, механізм. 
